\title{
New members of the editorial board
}

C Institut für Arbeitsmarkt- und Berufsforschung 2014

\section{Melanie Arntz}

Current position: Researcher at the Research Department "Labour Markets, Human Resources and Social Policy" at the Centre for European Economic Research (ZEW) in Mannheim, Germany; Assistant Professor for "Labour Markets" at the University of Heidelberg, Germany

Main fields of research: dynamics of employment over the life course, integration of labour markets, regional labour markets, labour markets and technological change

URL: http://www.zew.de/de/mitarbeiter/mar

\section{Laszlo Goerke}

Current position: Professorship holder of Business Administration, particularly Personnel Economics, and Director of the Institute for Labour Law and Industrial Relations in the European Union (IAAEU) at the University of Trier, Germany

Main fields of research: labour market and personnel economics, economics of welfare state, economical analysis of law, optimal taxation and tax evasion

URL: http://www.uni-trier.de/index.php?id=43468\&L=2

\section{Nicole Gürtzgen}

Current position: Senior Researcher at the Department of "Labour Markets, Human Resources and Social Policy" at the Centre for European Economic Research (ZEW) in Mannheim, Germany

Main fields of research: industrial relations, wage and employment dynamics, evaluation of labour market and social policies

URL: http://www.zew.de/de/mitarbeiter/ngu

\section{Aderonke Osikumino}

Current position: Professor of Economics and Head of the Chair in Statistics and Econometrics I at the University of Hohenheim, Germany

Main fields of research: applied econometrics, labour economics, program evaluation, economics of education URL: https://www.uni-hohenheim.de/person/aderonke-osikominu-3 